\title{
First Report of Lutzomyia (Nyssomyia) umbratilis Ward \& Frahia, 1977 outside of Amazonian Region, in Recife, State of Pernambuco, Brazil (Diptera: Psychodidae: Phlebotominae)
}

\author{
Valdir Q Balbino/ ${ }^{+}$, Carlos B Marcondes*, Bruce Alexander**, \\ Luciano KS Luna, Mônica MM Lucena, Antônio CS Mendes, Paulo P Ándrade
}

\begin{abstract}
Departamento de Genética, Centro de Ciências Biológicas, Universidade Federal de Pernambuco, Av. Prof. Moraes Rego s/nº, 50732-970 Recife, PE, Brasil *Departamento de Microbiologia e Parasitologia, Centro de Ciências Biológicas, Universidade Federal de Santa Catarina, Florianópolis, SC, Brasil **Centro de Pesquisas René Rachou-Fiocruz, Belo Horizonte, MG, Brasil
\end{abstract}

Lutzomyia umbratilis, a known vector of Leishmania guyanensis in the north of Amazon basin, has been exclusively found in the Amazonian region. Here we report for the first time the occurrence of this species in northeastern Brazil. The epidemiological importance of the occurrence of this species in the Atlantic Forest is commented.

Key words: Lutzomyia umbratilis - Phlebotominae - distribution - Brazil

Lutzomyia umbratilis Ward \& Frahia, 1978 has been reported in Bolivia, Brazil, Colombia, French Guyana, Guyana, Peru, Suriname and Venezuela (Young \& Duncan 1994, Burgos \& Hudson 1994) and Ecuador (F Le Pont 1996, pers. commun.). To date, it has only been found in the Amazonian region, usually associated to large tree trunks in primary forest (Ready et al. 1986). It was also observed in and near houses in French Guyana (Chippaux et al. 1984) and in the Island of São Luís (Maranhão, Brazil) (Rebêlo et al. 1999).

Lu. umbratilis feeds mostly on sloths (Christensen et al. 1982) and also bites man at the ground level and even in the tree canopy (Le Pont \& Pajot 1980). This occurs mostly when flies are disturbed from tree trunks, during the day, resulting in the transmission of Leishmania guyanensis Floch, 1954 to man, which is a common occurrence in the north of the Amazonas River but rarer to the south (Lainson et al. 1994). Lu. umbratilis was also found infected with Endotrypanum schaudinni Mesnil \& Brimont, 1908, a trypanosomatid parasite of sloths (Rogers et al. 1988).

${ }^{+}$Corresponding author. Fax: $+55-81-271.8569$. E-mail: valdir@npd.ufpe.br

Received 5 July 2000

Accepted 16 November 2000
Lu. umbratilis was collected at Dois Irmãos Park, Recife, State of Pernambuco ( $8^{\circ} 03^{\prime} 14$ 'S $34^{\circ} 52^{\prime} 52^{\prime \prime} \mathrm{W}, 4 \mathrm{~m}$ a. s. 1.). Dois Irmãos Park is a reserve of primary Atlantic rain forest, little disturbed in the past, that surrounds a small reservoir, which supplies water to Greater Recife. A total of 945 specimens of Lu. umbratilis was collected between 18 August 1999 and 16 February 2000 (Table), besides one male of Lutzomyia whitmani (Antunes \& Coutinho, 1939) and two males and five females of Lutzomyia choti (Floch \& Abonnenc, 1941). Lu. umbratilis is commonly found on trunks in several parts of the park and avidly bites the collectors in the forest at night.

The morphology of female flies matches the description of Ward and Frahia (1977, p. 314): spermathecae are annulated, with a long "head", and individual and common ducts are totally striated. Insects are predominantly brown, with pale markings. Insects from Recife were compared to Lu. umbratilis from French Guiana and Amazonian States and to Lutzomyia anduzei (Rozeboom, 1942) from Amazonas, belonging to Universidade Federal de Santa Catarina (UFSC) collection. Insects were deposited at the collections of Universidade Federal de Santa Catarina, Universidade Federal de Pernambuco and Faculdade de Saúde Pública (Universidade de São Paulo).

This finding is unexpected because of the distance and lack of continuity between the Amazo- 
nian forest and the Atlantic rain forest, specially to a weak flier like a sand fly. However, the Brazilian Platine and Amazonian regions share many species of phlebotomine sand flies (Martins \& Morales-Farias 1972) possibly because of past links between the Atlantic and the Amazonian rain forests. Information on the Lu. whitmani supports an ancient continuum of rain forest among Rondônia, Eastern Amazonia and Pernambuco (Ishikawa et al. 1999).

Lu. anduzei, a Amazonian species similar to Lu. umbratilis, was also found in the northeastern State of Bahia (Vexenat et al. 1986) and in the central State of Goiás (Coelho et al. 1965). However, as the last report was published before the description of Lu. umbratilis, this material should be reexamined. Lutzomyia wellcomei (Frahia, Shaw \& Lainson, 1971) and Lutzomyia complexa (Mangabeira, 1941), which are also very common in Amazonian primary forests, also occur situated in the northeastern region forests; the first is found in Ceará (Ready et al. 1983) and Pernambuco (Brandão-Filho et al. 1996) and the second in Pernambuco (Brandão-Filho et al. 1998). Lu. choti, Lutzomyia fischeri (Pinto, 1926), Lutzomyia lenti (Mangabeira, 1938) and Lutzomyia migonei (França, 1921) are also found on both regions (Young \& Duncan 1994). The last two are more ubiquitous and also occur in semiarid regions.

The phlebotomine fauna in the State of Pernambuco is not yet well known, and almost all insects collected so far came from endemic regions of cutaneous or visceral leishmaniasis. A previous study performed in the region of Greater Recife used Damasceno traps catches from tree holes, burrows and rock crevices habitats in 15 localities including Dois Irmãos reserve (Oliveira et al. 1977/ 1978). Eight species were recorded, but they did not include $\mathrm{Lu}$. umbratilis. We found that this species was homogeneously distributed over the entire reserve area, so it is possible that an increase in vector density has occurred in recent years, due to yet unknown environmental factors.

\section{TABLE}

Specimens of Lutzomyia umbratilis collected at Dois Irmãos Park, Recife, State of Pernambuco, between 18 August 1999 and 16 February 2000

\begin{tabular}{lccr}
\hline & \multicolumn{3}{c}{ Specimens } \\
\cline { 2 - 4 } Method & Males & Females & Total \\
\hline CDC-like light trap & 368 & 390 & 758 \\
Manual collection-trunks & 41 & 45 & 86 \\
Shannon light trap & 59 & 42 & 101 \\
\hline Total & 468 & 477 & 945 \\
\hline
\end{tabular}

Lu. umbratilis in Amazon seems to be more sensitive to vegetation modifications; in fact it was not found in gmelin plantations in Jari Project, while Lutzomyia flaviscutellata (Mangabeira, 1942) was very common in that plantation (Ready et al. 1983). Similarly, we have only found $L u$. umbratilis in well preserved forest areas around Recife, while other vector species, also found in forest areas, are seen in disturbed landscapes.

One of us (BA) collected, in 5 September 2000, some sand flies in crevices on tree trunks, $2 \mathrm{~h}$ after dawn, in the Dois Irmãos forest, identified by one of us (CBM) as Lu. umbratilis. This behaviour is similar to that of the flies from the north of Amazon basin (Le Pont \& Pajot 1980, Ready et al. 1986) and not to those from the State of Mato Grosso (Rangel et al. 1999). This aspect of its biology at Dois Irmãos forest should be studied.

The geographical isolation between populations of the Lu. umbratilis of northeast and Amazonian populations could result in morphological and molecular differences. More detailed studies are needed to genetic markers and morphological characterization.

Although there are records of cutaneous leishmaniasis in this region of Pernambuco (e.g., Aldeia Village and Camaragibe), the vector remains unknown. More studies are needed on Leishmania transmission among wild mammals and on the ecology of Lu. umbratilis similar to those that have been performed on the different populations of $L$. whitmani (Campbell-Lendrum et al. 1999).

\section{REFERENCES}

Brandão-Filho SP, Almeida FA, Valença HV 1996. Psychodopygus complexus in high endemicity region to American cutaneous leishmaniasis in Pernambuco, Brazil. Mem Inst Oswaldo Cruz 91 (Suppl.): 120.

Brandão-Filho SP, Brito MEF, Martins CAP, Sommer IB, Valença HF, Almeida FA, Gomes J 1998. Leishmaniose tegumentar americana em centro de treinamento militar localizado na Zona da Mata de Pernambuco, Brasil. Rev Soc Bras Med Trop 31: 575 578.

Burgos AM, Hudson JE 1994. Annotated list of the Phlebotominae (Diptera) of Suriname. Mem Inst Oswaldo Cruz 89: 171-178.

Campbell-Lendrum DH, Pinto MC, Brandão-Filho SP, Souza AA, Ready PD, Davies CR 1999. Experimental comparison of anthropophily between geographically dispersed populations of Lutzomyia whitmani (Diptera: Psychodidae). Med Vet Entomol 13: 299309.

Chippaux JP, Pajot FX, Barbier D 1984. La leishmaniose en Guyane française. 5. Note complementaire sur l'ecologie du vecteur dans le village forestier de Cacao. Cah ORSTOM ser Ent Med Parasitol 22: 213-218. 
Christensen HA, Arias JR, Vasquez AM, Freitas RA 1982. Hosts of sandfly vectors of Leishmania braziliensis guyanensis in the Central Amazon of Brazil. Am J Trop Med Hyg 31: 239-242.

Coelho MV, Cunha AS, Falcão AR 1965. Notas sobre um foco de calazar no sudoeste do estado de Goiás. Rev Bras Malar Doen Trop 17: 143-148.

Ishikawa EAY, Ready PD, Souza AA, Day JC, Rangel EF, Davies CR, Shaw JJ 1999. A mitochondrial DNA phylogeny indicates close relationships between populations of Lutzomyia whitmani (Diptera: Psychodidae, Phlebotominae) from the rain-forest regions of Amazônia and northeast Brazil. Mem Inst Oswaldo Cruz 94: 339-345.

Lainson R, Shaw JJ, Silveira FT, Souza AAA, Braga RR, Ishikawa EAY 1994. The dermal leishmaniases of Brazil, with special reference to the eco-epidemiology of the disease in Amazonia. Mem Inst Oswaldo Cruz 89: 435-443.

Le Pont F, Pajot FX 1980. La leishmaniose en Guyane française. 1. Étude de l'ecologie et de taux d'infection naturelle du vecteur Lutzomyia (Nyssomyia) umbratilis Ward \& Frahia, 1977 en saison sèche. Considerations épidémiologiques. Cah ORSTOM sér Ent Méd Paras 18: 359-382.

Martins AV, Morales-Farias EN 1972. Sobre a distribuição geográfica dos flebotomíneos americanos (Diptera, Psychodidae, Phlebotominae). Rev Bras Biol 32: 361-371.

Oliveira MHC, Lucena DT, Leal MCA, Nascimento AMLC 1977/1978. Flebotomíneos-gênero Lutzomyia França, 1924 da região metropolitana no Recife (D.P.). An Univ Fed Rural PE 2/3: 45-82.

Rangel EF, Azevedo ACR, Lima JB, Souza NA, Pereira T, Meneses CRV, Costa WA 1999. Ecologia da leishmaniose cutânea no Estado de Mato Grosso. I. Distribuição vertical da fauna flebotomínica (Diptera: Psychodidae; Phlebotominae). Rev Soc Bras Med Trop 32 (Supl. I): 25-26.
Ready PD, Lainson R, Shaw JJ 1983. Leishmaniasis in Brazil: XX. Prevalence of "enzootic rodent leishmaniasis" (Leishmania mexicana amazonensis), and apparent absence of "pian-bois" (Le. braziliensis guyanensis) in plantations of introduced tree species and in other non-climax forest in eastern Amazonia. Trans R Soc Trop Med Hyg 77: 775-785.

Ready PD, Lainson R, Shaw JJ, Ward RD 1986. The ecology of Lutzomyia umbratilis (Diptera, Psychodidae), the major vector to man of Leishmania braziliensis guyanensis in northeastern Amazonian Brazil. Bull Ent Res 76: 21-40.

Ready PD, Ribeiro AL, Lainson R, Alencar JE, Shaw JJ 1983. Presence of Psychodopygus wellcomei (Diptera: Psychodidae), a proven vector of Leishmania braziliensis, in Ceará State. Mem Inst Oswaldo Cruz, 78: 235-236.

Rebêlo JMM, Araujo JAC, Carvalho ML, Barros VLL, Silva FL, Oliveira ST 1999. Flebótomos (Diptera, Phlebotominae) da Ilha de São Luís, zona do Golfão Maranhense, Brasil. Rev Soc Bras Med Trop 32: 247253.

Rogers WO, Burheim PF, Wirth DF 1988. Detection of Leishmania within sandflies by kynetoplast DNA hybridization. Am J Trop Med Hyg 39: 434-439.

Vexenat JA, Barretto AC, Cuba-C C, Marsden PD 1986. Características epidemiológicas da leishmaniose tegumentar americana em uma região endêmica do estado da Bahia. III. Fauna flebotômica. Mem Inst Oswaldo Cruz 81: 293-301.

Ward RD, Frahia H 1977. Lutzomyia umbratilis, a new species of sandfly from Brazil (Diptera: Psychodidae). J Med Entomol 14: 313-317.

Young DG, Duncan MA 1994. Guide to the Identification and Geographic Distribution of Lutzomyia Sand Flies in Mexico, the West Indies, Central and South America (Diptera: Psychodidae). Amer Entomol Inst, Gainesville, 881 pp. 
318

L. (N.) umbratilis in Pernambuco - Valdir Q Balbino et al. 